\title{
Leukocytes from Four Patients with Complete or Partial Leu-CAM Deficiency Contain the Common $\beta$-Subunit Precursor and $\beta$-Subunit Messenger RNA
}

\author{
Nava Dana," Linda K. Clayton," Daniel G. Tennen, " Mark W. Pierce, \\ Peter J. Lachmann,' S. Alex Law," and M. Amin Amaout* \\ ${ }^{*}$ Renal and Immunology Divisions, The Children's Hospital, ${ }^{\ddagger}$ Hematology/Oncology Division, Beth Israel Hospital, ${ }^{\S}$ Howard Hughes \\ Medical Institute and Endocrinology Division, Massachusetts General Hospital and Harvard Medical School, Boston, Massachusetts; \\ 'Mechanisms in Tumor Immunity Unit, Medical Research Council (MRC) Center, Cambridge, and "MRC Immunochemistry Unit, \\ Oxford University, United Kingdom
}

\begin{abstract}
Deficiency of a family of three leukocyte adhesion molecules (Leu-CAM) is associated with recurrent and life-threatening bacterial infections in man. Each of the three antigens, Mo1, LFA-1, and Leu M5 has a distinct alpha subunit noncovalently associated with a common beta subunit that appears to be required for the expression of these antigens on the cell surface. To investigate the molecular basis of Leu-CAM deficiency, we studied leukocytes from four unrelated patients suffering from complete or partial Leu-CAM deficiency using immunoprecipitation of metabolically labeled proteins, RNA extraction, and Northern blot analysis. We found that $B$ cells from all four patients synthesized a normal sized beta subunit precursor that either failed to "mature" or matured only partially to the membrane expressed form. B cells from all four patients also had a single normal sized beta subunit mRNA of $\sim 3.4 \mathrm{~kb}$. Leu-CAM deficiency, in these unrelated patients, is not due to the absence of the beta chain gene or to aberrant splicing of its mRNA and are consistent with a defective beta subunit gene resulting in abnormal posttranslational processing of the synthesized molecule.
\end{abstract}

\section{Introduction}

Among the basic biologic functions of leukocytes are chemotaxis, phagocytosis, cell-mediated cytotoxicity, and natural killing. That these apparently unrelated functions are in fact mediated by a family of related cell surface molecules has been established through the identification of a number of patients suffering from recurrent and life-threatening bacterial infections whose leukocytes exhibit abnormalities in adhesion-dependent functions such as phagocytosis, chemotaxis, adhesion to endothelial cell monolayers, cell-mediated cytotoxicity, and natural killing (reviewed in ref. 1). Leukocytes from these patients either lack or have markedly reduced levels of three antigens on the surface of circulating leukocytes $(2,3)$. These three glycoproteins, named

Address reprint requests to Dr. Arnaout, Renal Division, The Children's Hospital, Boston, MA 02115.

Received for publication 30 September 1986.

J. Clin. Invest.

(C) The American Society for Clinical Investigation, Inc.

0021-9738/87/03/1010/06 \$1.00

Volume 79, March 1987, 1010-1015
Mo1, LFA-1, and Leu M5 (p 150, 95) are heterodimers, each consisting of a distinct alpha subunit $(155,175$, and $140 \mathrm{kD}$, respectively) noncovalently linked to a common beta subunit of $94 \mathrm{kD}$ (4-6). Amino acid sequencing of these purified proteins and nucleotide sequencing of cDNA clones revealed remarkable homologies with other cell adhesion molecules such as the fibronectin receptor and the platelet IIb/IIIa complex (7, 8). Mol and Leu M5 are expressed on monocytes, granulocytes, and null cells, whereas LFA-1 is present, in addition, on T and B lymphocytes (4-6). Monoclonal antibodies (MAbs) ${ }^{1}$ directed against this family of molecules reproduce on normal cells the defects seen in genetically deficient leukocytes $(1,2)$.

Leu-CAM deficiency is an inherited disorder. In most families, leukocytes from both parents have $\sim 50 \%$ of normal levels of Leu-CAM antigens suggesting an autosomal basis for this disease. In other cases, the pattern of inheritance suggests an Xlinked disorder (9). In yet other families, the mode of inheritance is less certain $(10,11)$.

The molecular basis for Leu-CAM deficiency is unclear. Two recent studies demonstrated that metabolically labeled leukocytes from patients suffering from partial or complete Leu-CAM deficiency synthesize the alpha subunits but not the beta subunit of Leu-CAM and concluded that the disease is secondary to a primary deficiency of the common beta subunit $(12,13)$. These findings, however, could not explain the phenotypic variation in Leu-CAM surface expression among affected patients.

In this report, we investigated the molecular basis of LeuCAM deficiency in four unrelated patients with either the partial or complete forms of the disease. Lymphocytes from all four patients synthesized normal amounts of a beta subunit precursor that either failed to mature or only partially matured to the 94kD surface membrane expressed form. RNA extracted from all four patients' leukocytes contained a single species of $\beta$ subunit mRNA of $3.4 \mathrm{kD}$ similar in mobility to that present in normal cells. We conclude that Leu-CAM deficiency in these four patients is not due to a lack of the beta subunit gene, but to a defect affecting the posttranslational processing of a beta chain precursor. This defect could result from distinct mutation(s) in the structural beta subunit gene leading to synthesis of abnormal beta chains, which may vary in their capacity to form alphabeta complexes. This could result in the quantitative differences in Leu-CAM surface membrane expression observed in this disorder.

1. Abbreviations used in this paper: EBV, Epstein-Barr virus; MAbs, monoclonal antibodies; PAGE, polyacrylamide gel electrophoresis; PMSF, phenylmethylsulfonyl fluoride. 


\section{Methods}

Subjects. We studied four unrelated patients with Leu-CAM deficiency and three normal subjects. The clinical history, pathologic findings and Leu-CAM phenotypes in all four patients have been reported $(2,9,10$, 14). Immunofluorescence analysis (Fig. 1) of Epstein-Barr virus (EBV)transformed B lymphocytes from patients 1 (14) and 2 (patient 1 in ref. $10)$ failed to express the beta subunit on the surface membrane $(<2 \%$ of normal). Lymphocytes from patients $3(2)$ and 4 (9) expressed $\sim 10$ $20 \%$ of normal levels of this antigen. In addition, LFA-1 deficient EBVtransformed cells from all four patients did not spontaneously aggregate in culture as normal cells do (15) (not shown). These cells are therefore both phenotypically and functionally representative of other nontransformed cells from these patients.

Antibodies and beta subunit-specific complementary DNA probe. A mouse monoclonal antibody directed against the alpha chain of LFA-1 was kindly provided by Dr. Hergen Spits (University of Amsterdam) (16). Mouse monoclonal antibodies directed against human $\beta_{2}$-microglobulin or to the beta subunit of Leu-CAM (TS18) were kindly provided, respectively, by Dr. Lee Nadler (17) and Steven J. Burakoff (Dana Farber Cancer Institute, Boston, MA). A rabbit monospecific antibody to human $\beta_{2}$-microglobulin was bought from Miles Laboratories, Naperville, IL. A rabbit polyclonal antibody directed against the beta subunit was developed as follows: Human Mol was purified from granulocytes by Lentil lectin Sepharose chromatography followed by affinity chromatography on a monoclonal anti-Mol Sepharose column (7) (Fig. 2 A). Following sodium dodecyl sulfate polyacrylamide gel electrophoresis (SDS PAGE) the beta subunit was electroeluted (18) (Fig. $2 A$ ), emulsified in complete Freund's adjuvant and injected subcutaneously into rabbits. After two boosts, in incomplete Freund's adjuvant, animals were bled, and the

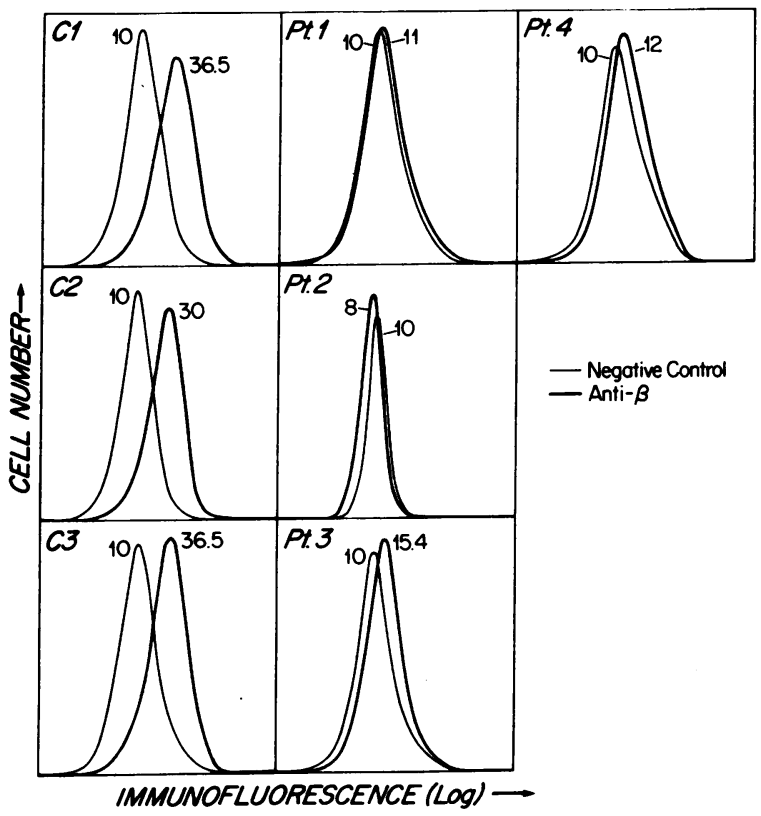

Figure 1. Immunofluorescence analysis of EBV-transformed B cells from three controls $(\mathrm{C} 1-3)$ and four patients with Leu-CAM deficiency. Cells were stained with TS18 (anti-beta chain monoclonal antibody) or with a nonreactive mouse monoclonal antibody as previously described (2). Data are presented as single parameter histograms. The $x$-axis represents relative fluorescence intensity ( 256 channel resolution; log. scale). For quantitative comparisons, the mean peak channel of the fluorescence was converted into a linear value (neg. control assigned 10) as indicated in arabic numerals, using a calibration factor. $\beta_{2}$-Microglobulin-dependent peak channel fluorescence (arbitrary units) on leukocytes from patients $1-4$ were $301,348,332$, and 261 , respectively, compared with 249,249 , and 300 for controls C1-3, respectively.
A

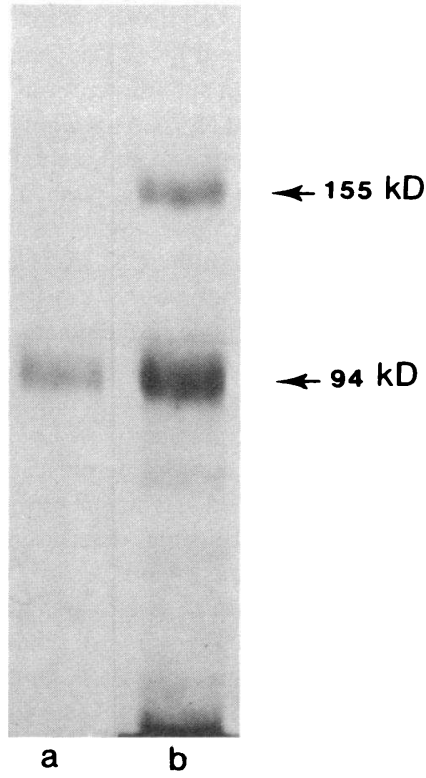

B

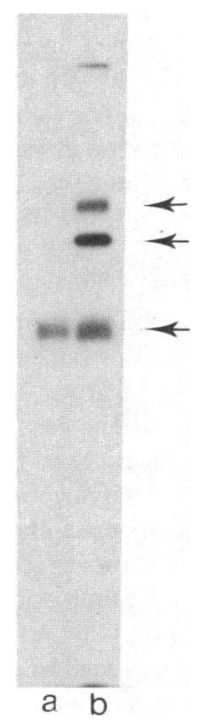

Figure 2. Development and characterization of the rabbit anti-beta subunit antibody. (A) Silver stain of a 7.5\% SDS PAGE showing the purified Mol antigen heterodimer (lane $b$ ) and an aliquot of the geleluted beta subunit $(94 \mathrm{kD}$ ) used to immunize a rabbit (lane $a$ ). (B) Autoradiograph of a 6\% SDS PAGE showing the immunoprecipitates from ${ }^{125}$ I surface labeled human monocytes (4) using rabbit anti-beta antibody (lane $a$ ) and TS18 MAb (lane $b$ ). Arrows (top to bottom) point at LFA-1/Mol (usually unresolved on SDS PAGE in monocytes), Leu M5 and beta subunit, respectively.

$40 \%$ ammonium sulfate cut was used for immunoprecipitations. Immunoprecipitations from ${ }^{125}$ I-surface labeled monocytes using TS18 monoclonal antibody and rabbit anti-beta subunit antibody followed by SDS-PAGE revealed that both antibodies immunoprecipitate the beta chain of the Leu-CAM complex (Fig. $2 B$ ). Furthermore, preclearance of ${ }^{125}$ I monocytes or ${ }^{35} \mathrm{~S}-\mathrm{EBV}$ cell lysate with rabbit anti-beta removed the protein complex identified with TS18 (not shown). Western blot analysis (19) using polyclonal anti-beta subunit antibody and granulocyte lysates from a normal individual and a patient with Leu-CAM deficiency (patient 1) revealed a major band at $94 \mathrm{kD}$ in normal cells but not in the beta subunit deficient patient's cells (data not shown). A beta subunitspecific complementary DNA (cDNA) clone, 2.8 kilobases (kb) in length, was isolated by screening a cDNA library (generated from phorbol myristate acetate-stimulated U937 cells) with oligonucleotides derived from the purified beta chain (8).

Metabolic labeling. Normal or patient derived EBV-lymphoblastoid cells were washed three times and incubated at $5 \times 10^{6} / \mathrm{ml}$ in methionine free RPMI 1640 medium supplemented with 5\% bovine serum albumin (BSA). [ ${ }^{35}$ S]Methionine (NEG-009A, $800 \mathrm{Ci} / \mathrm{mmol}$, New England Nuclear, Boston, MA) was added and the cells were cultured for $90 \mathrm{~min}$ at $37^{\circ} \mathrm{C}$. Cells were either collected at this time, washed with methionine containing RPMI 1640, treated with diisopropylfluorophosphate ( $5 \mathrm{mM}$, $10 \mathrm{~min}$, on ice), washed, detergent solubilized in PBS containing $1 \%$ Triton X 100 and $2 \mathrm{mM}$ phenylmethylsulfonyl fluoride (PMSF) (10 $\min , 4^{\circ} \mathrm{C}$ ) and the detergent soluble fraction separated after centrifugation in an Eppendorf microfuge $\left(15 \mathrm{~min}, 4^{\circ} \mathrm{C}\right)$. Alternatively, following an initial "pulse," cells $\left(5 \times 10^{7}\right)$ were washed and chased with unlabeled methionine. At various time points, cells were collected and the detergent soluble fraction was obtained as described above.

${ }^{125}$ I surface labeling of EBV-transformed B cells or monocytes was done as previously described (2).

Immunoprecipitation. The detergent soluble fraction derived from 5 to $50 \times 10^{6}$ cells was diluted $1: 1$ in PBS containing $0.5 \% \mathrm{Na}$ deoxycholate and $1 \% 2 \times$ crystallized SDS. The lysate was precleared two times by 
incubation for $1 \mathrm{~h}$ at $4^{\circ} \mathrm{C}$ with $300 \mu \mathrm{l}$ of $10 \%$ G-sorb (IG-sorb, The Enzyme Center Inc., Malden, MA). The precleared lysate was then incubated with $45 \mu \mathrm{l}$ of purified polyclonal anti-beta subunit antibody (15 $\mathrm{mg} / \mathrm{ml}$ ) or with a nonimmune rabbit Ig overnight at $4^{\circ} \mathrm{C} .200 \mu \mathrm{l}$ of $10 \%$ G-sorb was washed, pelleted then added to the mixture and incubation continued for an additional $45 \mathrm{~min}$. The G-sorb was then washed two times with $\mathrm{PBS}$ containing $0.5 \%$ Triton- $\mathrm{X} 100,0.25 \%$ deoxycholate, $0.5 \%$ SDS, $2 \mathrm{mM}$ PMSF and crystallized BSA $(5 \mathrm{mg} / \mathrm{ml}$, ICN, Cleveland, $\mathrm{OH})$. This was followed by four washes in the same buffer containing no BSA. In some experiments, no SDS was ihcluded in the reaction or washing buffers. Pellets were extracted with sample buffer and analyzed on $7.5 \%$ or $5-15 \%$ gradient polyacrylamide gels according to Laemmli (20). The gels were then fixed, enhanced with Enhance (New England Nuclear) and fluorographed using Kodak XAR film in the presence of intensifying screens. The amount of antibody used was sufficient to immunoprecipitate $\sim 90 \%$ of the corresponding antigen as determined in preliminary sequential immunoprecipitation experiments.

Immunoprecipitations using MAb were done in a similar manner except that no SDS was included in any of the buffers. $5 \mu$ l of the MAb was added to cell lysate, and incubated overnight at $4^{\circ} \mathrm{C} .2 \mathrm{~h}$ after the addition of $5 \mu$ l of a second rabbit anti-mouse Ig antibody (Dako Corp., Santa Barbara, CA), G-Sorb (100 $\mu$ l) was added and followed by a 30min incubation. Washes were done as detailed above.

Radioactivity in bands corresponding to beta subunit precursor or to $\beta_{2}$-microglobulin (immunoprecipitated from an equal volume of cell lysate) was quantified as peak area after scanning hypersensitized fluorograms (21). The ratio of radioactivity (in arbitrary units) obtained from the beta subunit precursor to that obtained from $\beta_{2}$-microglobulin was determined and compared in normal and deficient cells.

Endoglycosidase- $\mathrm{H}$ treatment of immunoprecipitates containing ${ }^{35} \mathrm{~S}$ labeled beta subunit precursor was performed exactly as described (22).

$R N A$ isolation and analysis. Total cellular RNA and poly $(\mathrm{A})^{+}$RNA were isolated from EBV-transformed $B$ cell lines derived from normals and patients $(23,24)$. Total RNA was quantitated by absorbance at an optical density of $260 \mathrm{~nm}\left(1 \mathrm{OD}_{260} \mathrm{U}=40 \mu \mathrm{g}\right.$ of RNA per ml). Total cellular RNA $(\sim 20 \mu \mathrm{g})$ or poly $(\mathrm{A})^{+}$RNA from each subject were denatured with formaldehyde, subjected to agarose-gel electrophoresis, transferred to nitrocellulose filters, and hybridized with a ${ }^{32}$ P-labeled beta subunit-specific cDNA probe or with a ${ }^{32} \mathrm{P}$-labeled beta actin-specific probe (25) (Northern blot analysis) (26). The beta subunit specific cDNA insert and the beta actin-specific $2 \mathrm{~kb}$ insert contained in plasmid pA1 were labeled with ${ }^{32} \mathrm{P}$ essentially as described (27).

\section{Results}

Biosynthesis of the common beta subunit in normal and Leu$C A M$ deficient $E B V$-transformed $B$ cells. When EBV-transformed $B$ cells from normal individuals are pulsed with $\left[{ }^{35} \mathrm{~S}\right]$ methionine for $90 \mathrm{~min}$, and the detergent soluble fraction immunoprecipitated with rabbit anti-beta subunit antibody, a single precursor with an apparent molecular mass of $85 \mathrm{kD}$ appeared (Fig. $3 \mathrm{~A}$ ). If SDS is omitted from the immunoprecipitation procedure, an additional band of $\sim 170 \mathrm{kD}$ representing the LFA-1 precursor was also seen (not shown). After an 18-h chase the beta subunit precursor was chased to a $94-\mathrm{kD}$ band (Fig. $3 \mathrm{~A}$ ). This band had an identical mobility to the beta subunit immunoprecipitated from ${ }^{125}$ I surface labeled EBV-transformed cells (not shown). Endo-H treatment of the beta chain precursor reduced its molecular mass to $73 \mathrm{kD}$ (Fig. $3 \mathrm{~B}$ ) indicating that it already contains "high mannose" type oligosaccharides. The processing of the normal beta precursor in EBV cells to the "mature" form was slow and incomplete. In three separate experiments, only $30-40 \%$ of the precursor matured after $18-24 \mathrm{~h}$ of

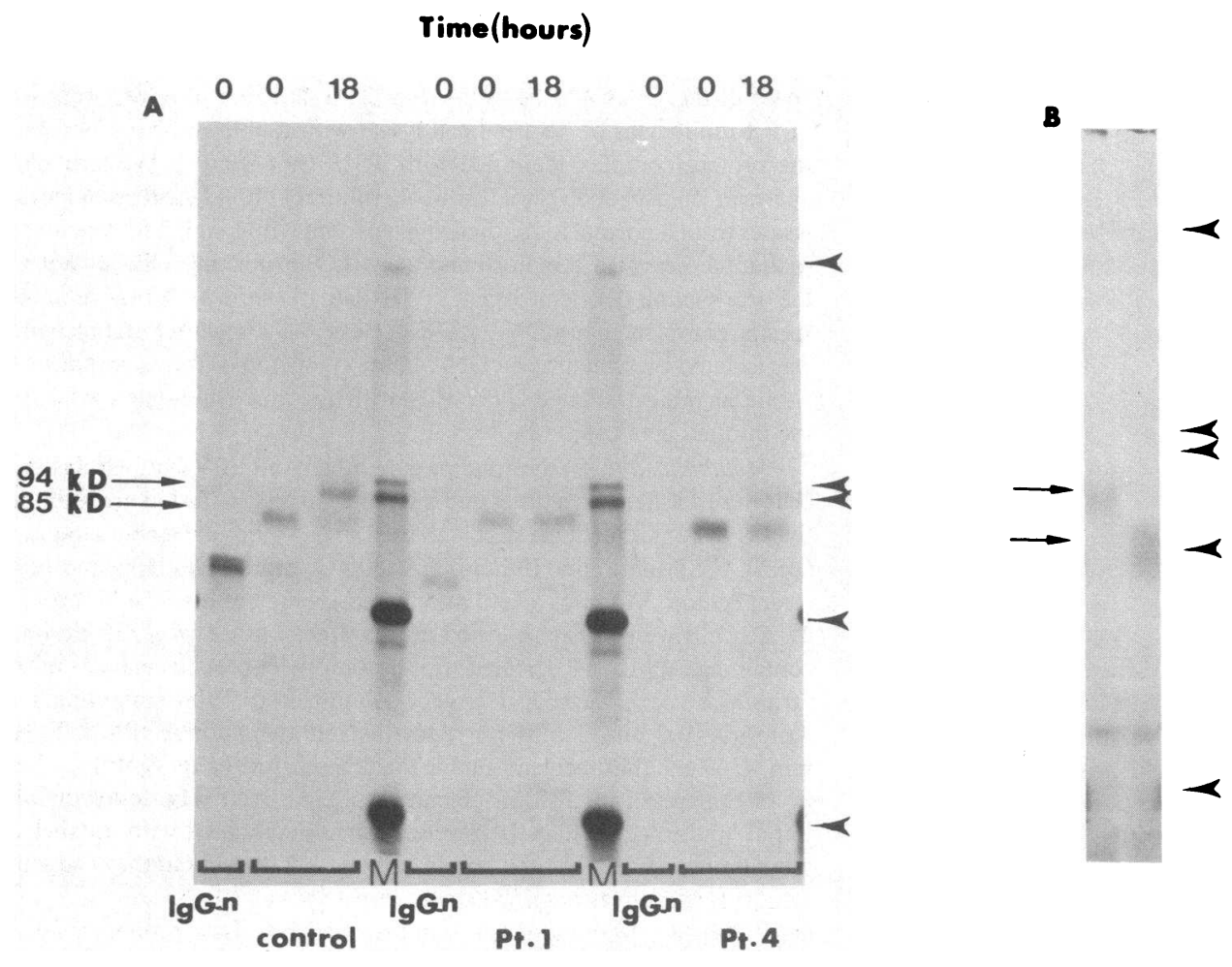

Figure 3. (A) Autoradiograph of a 7.5\% SDS PAGE showing biosynthesis of the beta subunit in EBVtransformed cells from a control subject and from patients (Pts) 1 and 4. A beta subunit precursor of $85 \mathrm{kD}$ was seen in control or patients' cells that were pulsed for $90 \mathrm{~min}$ with $\left[{ }^{35} \mathrm{~S}\right]$ methionine ( 0 time point). The ratios of the precursor to that of $\beta_{2^{-}}$ microglobulin (quantitated as described in Methods) in control, patients 1 , and 4 were $0.296,0.370$, and 0.396 , respectively. A control rabbit serum directed against human Ig (IgG-N) immunoprecipitated from these $B$ cell lines the heavy chain of synthesized Ig. After $18 \mathrm{~h}$, the beta subunit was chased to the 94-kD membrane form in control cells but not in patient 1 and only partially in patient $4 . M$, molecular weight markers: myosin, $200 \mathrm{kD}$; phosphorylase a, $92.5 \mathrm{kD}$; bovine albumin, $68 \mathrm{kD}$; carbonic anhydrase $40 \mathrm{kD}$ (arrow heads). (B) Autoradiograph of a $7.5 \%$ SDS PAGE showing that the molecular mass of the beta subunit precursor is reduced from 85 $\mathrm{kD}$ (upper arrow) in the absence (left lane) of Endo-H to $73 \mathrm{kD}$ (lower arrow) in its presence (right lane). Molecular weight markers (arrow heads) were the same used in (A). 
"chase." These data suggest that under normal conditions, only a fraction of the precursor beta subunit matures.

A beta chain precursor of normal mobility was present in normal amounts in metabolically labeled EBV cells from patients with partial or complete Leu-CAM deficiency (Fig. $3 A$ ). In patient 1 (14) (with total [ $<2 \%$ ] lack of Leu-CAM surface expression), the beta precursor did not mature by $18 \mathrm{~h}$ and was eventually degraded (Fig. $3 \mathrm{~A}$ ). Longer chase periods (up to $48 \mathrm{~h}$ ) did not result in a detectable mature form (not shown). In patient 4 (with partial deficiency), trace amounts of a mature beta subunit were detected (Fig. $3 \mathrm{~A}$ ) in agreement with the small amounts of this antigen that were detected on the surface ( 2 and Fig. 1). Results obtained in patients 2 and 3 were similar to those in patients 1 and 4, respectively (not shown). In all patients comparable amounts of $\beta_{2}$-microglobulin were synthesized and surface expressed as in normal cells (legends to Figs. 1 and 3).

Northern blot analysis of beta chain $m R N A$. To examine the possibility that Leu-CAM deficiency is due to a transcriptional defect resulting in synthesis of an mRNA of abnormal mobility, total cellular and poly(A) ${ }^{+}$RNA from normal and Leu-CAM deficient cells were subjected to Northern blot analysis using a single stranded beta subunit cDNA probe. A single species mRNA was present in all four patients that had a mobility on agarose gels similar to that derived from normal cells (Fig. $4 \mathrm{~A}$ and $B$ ).

\section{Discussion}

The present investigation was undertaken in order to study the biosynthesis of the beta subunit common to LFA-1, Mol, and Leu M5 in leukocytes from unrelated patients with the complete or incomplete forms of Leu-CAM deficiency. A previous study (12) on one of the patients studied here (patient 1) did not detect any beta precursor despite the presence of normal alpha precursor. It was concluded that Leu-CAM deficiency is secondary to a primary deficiency of the beta subunit. A similar conclusion was made in a follow-up study (13). The studies reported here indicate that all four unrelated patients, including patient 1 , synthesize a beta chain precursor that has a normal mobility on SDS PAGE and in amounts comparable to those present in control cells (Fig. 3). Either little or no detectable maturation of the precursors to the surface expressed form occurs in patients with "partial" or "complete" form of the deficiency, respectively, suggesting that little or none reach the trans region of the Golgi complex (28). The discrepant findings regarding the synthesis of the beta subunit in patient 1 in this study and in the study by Springer et al. (12) may be explained by the fact that TS18, the monoclonal antibody directed against the beta subunit used by Springer et al. does not seem to recognize the beta precursor in normal cells (6).

The availability of a cDNA clone encoding for the common beta subunit allowed further probing into the molecular basis of Leu-CAM deficiency. The beta chain mRNA had an approximate size of $3.4 \mathrm{~kb}$ in normal cells. Leu-CAM-deficient cells also contained a single form of mRNA that had normal mobility and appeared to be present in normal amounts, again indicating that Leu-CAM-deficient cells have the beta chain gene and that synthesis of an abnormal beta chain precursor is not $2^{\circ}$ to a transcriptional defect resulting in mRNA of abnormal mobility on agarose gel electrophoresis. Similar analysis in other LeuCAM-deficient patients will be necessary to determine if true
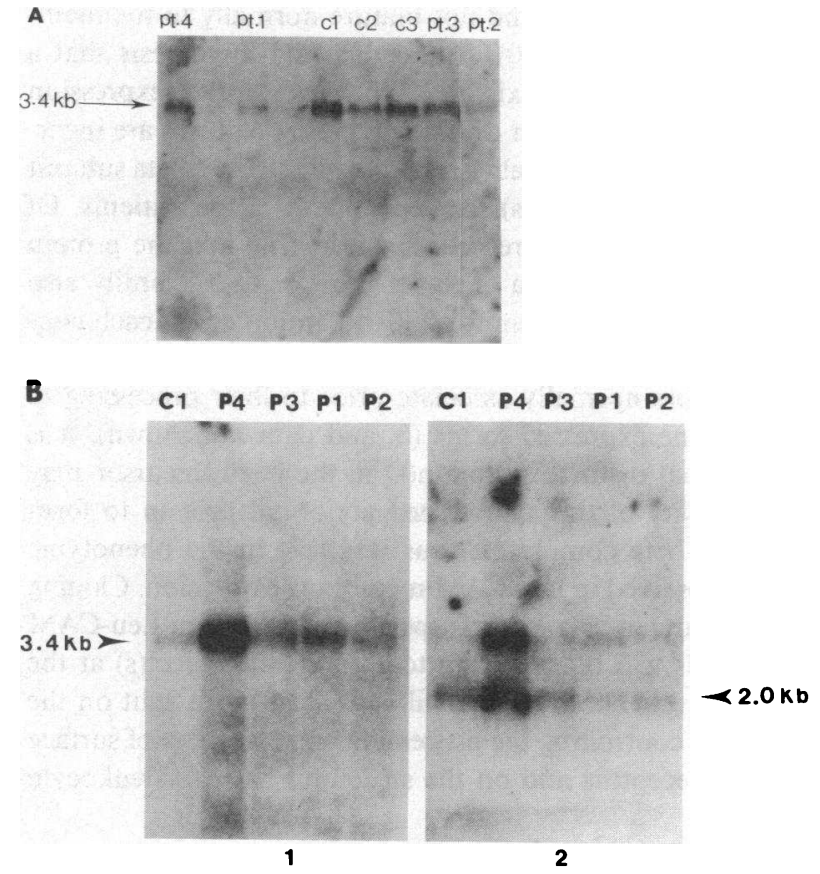

Figure 4. (A) Autoradiograph of a Northern blot showing beta chain mRNA in EBV cell lines from three controls $(\mathrm{Cl}, \mathrm{C} 2$, and $\mathrm{C} 3)$ and four Leu-CAM deficient patients (patients 1-4). Total RNA $(\sim 20 \mu \mathrm{g})$ from each subject was applied and hybridized with a beta chain [ $\left.{ }^{32} \mathrm{P}\right] \mathrm{cDNA}$ probe. Both controls and patients had a single sized beta chain mRNA of $3.4 \mathrm{~kb}$. (B) Autoradiograph of a Northern blot in which poly $(\mathrm{A})^{+}$RNA from one control (C1) and four patients (P1-4) was probed either with ${ }^{32} \mathrm{P}$-labeled beta chain CDNA (panel 1) or with ${ }^{32} \mathrm{P}$-labeled beta-actin cDNA (panel 2). RNA from all five individuals contained the same sized beta chain mRNA. The increase in beta chain mRNA noted in patient 4 (as compared with the control and the other patients) appears to be secondary to increased loading of RNA since a proportional increase in beta-actin mRNA is seen in the same sample. The ratios of radioactivity of the beta chain mRNA band to that of the 2-kb beta-actin mRNA band (as determined by densitometric scanning of the autoradiographs) were as follows: $\mathrm{Cl}$, $0.92 ; \mathrm{P} 4,1.17 ; \mathrm{P} 3,1.01 ; \mathrm{P1}, 1.64$; and P2, 0.76. In the autoradiograph of panel 2 , the higher band represents the remaining radioactivity associated with the beta chain mRNA that was not completely washed off before rehybridization with the ${ }^{32} \mathrm{P}$-beta-actin probe.

differences in the amount of mRNA exist and if the defect could also arise from a gene deletion.

The nature of the defect that results in the arrest of maturation of the beta subunit in our Leu-CAM-deficient cells is unclear. Abnormal posttranslational processing has been observed in many other systems in which there were mutations in the structural genes for glycoproteins (29). Cells from Leu-CAM deficient patients do not have defects in the production, accumulation, or translation of the beta messenger RNAs, suggesting that the basic defect is a mutation affecting the normal movement of the beta chain from the rough endoplasmic reticulum to the Golgi complex. An analogous transport deficient mutation has been recently identified in humans with familial hypercholesterolemia resulting in a complete or partial surface expression of the LDL receptor (30). A deletion involving 7-12 amino acids from the third cysteine-rich repeat of the ligand binding domain of the LDL receptor gene from one patient produced a receptor 
molecule precursor that did not mature normally to the membrane expressed form (30). This led to the hypothesis that a gatekeeper protein may exist that blocks the surface expression of proteins whenever their disulfide bonding patterns are incorrect (30). Similar abnormality(ies) in the Leu-CAM beta subunit may underlie the defect(s) seen in some of these patients. Of potential interest in this regard, is the finding that the protein coding region of the beta chain of the Leu-CAM family also contains three repeating units of 30-40 amino acids, each containing eight cysteine residues (8). Since the alpha and beta subunit precursors normally associate prior to their processing to the membrane expressed forms (6, and data not shown), it is also likely that distinct mutation(s) in the beta precursor may alter the ability of this synthesized abnormal protein to form stable alpha-beta complexes, thus resulting in the phenotypic variations observed in Leu-CAM membrane expression. Cloning and sequencing of beta subunit specific cDNAs from Leu-CAM deficient cells will be necessary to identify the defect(s) at the molecular level. These studies will also shed more light on the mechanisms controlling the processing and transport of surface membrane receptors and on the structural basis for leukocyte adhesion.

\section{Acknowledgments}

We acknowledge the help of Dr. Zhongyong $\mathrm{Li}$, the technical assistance of Mr. Scott Pendergast, and thank Ms. Margaret Oakes for secretarial assistance.

Supported by U. S. Public Health Service grants AI21963, CA41456, a Junior Faculty Research Award from the American Cancer Society JFRA-140 to Dr. Tennen, and March of Dimes grant 1011. Dr. Dana is a Fellow of the Arthritis Foundation. Dr. Arnaout is an Established Investigator of the American Heart Association.

\section{References}

1. Arnaout, M. A., N. Dana, J. Pitt, and R. F. Todd III. 1985. Deficiency of two human leukocyte surface membrane glycoproteins (Mol and LFA-1). Fed. Proc. 44:2664-2670.

2. Arnaout, M. A., H. Spits, C. Terhorst, J. Pitt, and R. F. Todd III. 1984. Deficiency of a leukocyte surface glycoprotein (LFA-1) in two patients with Mol deficiency. Effects of cell activation on Mol/LFA-1 surface expression in normal and deficient leukocytes. J. Clin. Invest. 74:1291-1309.

3. Lanier, L. L., M. A. Arnaout, R. Schwarting, N. L. Warner, and G. D. Ross. 1985. P150/95, a third member of the LFA-1/CR3 polypeptide family identified by anti-Leu M5 monoclonal antibody. Eur. $J$. Immunol. 15:713-718.

4. Todd, R. F. III, L. M. Nadler, and S. F. Schlossman. 1981. Antigens on human monocytes identified by monoclonal antibodies. J. Immunol. 126:1435-1442.

5. Trowbridge, I. S., and M. B. Omary. 1981. Molecular complexity of leukocyte surface glycoproteins related to the macrophage differentiation antigen Mac-1. J. Exp. Med. 154:1517-1524.

6. Sanchez-Madrid, F., J. A. Nagy, E. Robbins, P. Simon, and T. A. Springer. 1983. A human leukocyte differentiation antigen family with distinct alpha subunits and a common beta subunit: the lymphocytefunction associated antigen (LFA-1), the C3bi complement receptor (OKM1/Mac-1), and the p150,95 molecule. J. Exp. Med. 158:17851795.

7. Pierce, M. W., E. Remold-O'Donnell, R. F. Todd III, and M. A. Arnaout. 1986. N-terminal sequence of human leukocyte glycoprotein Mo1. Conservation across species and homology to platelet IIb/IIIa. Biochim. Biophys. Acta. In press.
8. Law, S. K. A., J. Gagnon, J. E. K. Hildreth, A. C. Willis, and A. J. Wong. 1987. Structural homology between the beta-subunit of the human LFA-1/CR3/p150,95 cell surface adhesion glycoproteins and a fibronectin binding protein, integrin, from chicken fibroblasts. Proceedings of the Third International Workshop and Conference on Human Leukocyte Surface Antigens. A. McMichael, editor. In press.

9. Crowley, C. A., J. T. Curnett, R. E. Rosin, J. Andre-Schwartz, J. I. Gallin, M. Klempner, R. Snyderman, F. S. Southwick, T. P. Stossel, and B. M. Babior. 1980. An inherited abnormality of neutrophils and its genetic transmission and its association with a missing protein. $N$. Engl. J. Med. 302:1163-1168.

10. Ross, G. G., M. J. Thompson, T. A. Walport, T. A. Springer, J. V. Watson, R. H. R. Ward, J. Lida, S. L. Newman, R. A. Harrison, and P. J. Lachmann. 1985. Characterization of patients with an increased susceptibility to bacterial infections and a genetic deficiency of leukocyte membrane complement receptor type III and the related membrane antigen LFA-1. Blood. 66:882-890.

11. Miedema, R., P. A. T. Tetteroo, P. G. Terpatra, G. Keizer, M. Roos, R. S. Weening, C. M. R. Weemaes, D. Roos, and C. J. M. Melief. 1985. Immunologic studies with LFA-1 and Mo1-deficient lymphocytes from a patient with recurrent bacterial infections. J. Immunol. 134:30753081.

12. Springer, T. A., W. S. Thompson, L. J. Miller, F. C. Schmalsteig, and D. C. Anderson. 1984. Inherited deficiency of the Mac-1, LFA-1 p150,95 glycoprotein family and its molecular basis. J. Exp. Med. 160: 1901-1918.

13. Lisowska-Grospierre, B., M. C. H. Bohler, A. Fisher, C. Mawas, T. A. Springer, and C. Griscelli. 1986. Defective membrane expression of the LFA-1 complex may be secondary to the absence of the chain in a child with recurrent bacterial infections. Eur. J. Immunol. 16:205208.

14. Anderson, D. C., F. C. Schmalstieg, M. A. Arnaout, S. Kohl, M. F. Tosi, N. Dana, G. J. Buffone, B. J. Hughes, B. R. Brinkley, W. D. Dickey, J. S. Abramson, T. Springer, L. A. Boxer, J. M. Hollers, and C. W. Smith. 1984. Abnormalities in polymorphonuclear leukocyte function associated with a heritable deficiency of a high molecular weight surface glycoprotein (GP138). Common relationship to diminished cell adherence. J. Clin. Invest. 74:536-551.

15. Patarroyo, M., P. G. Beatty, J. W. Fabre, and C. G. Gahmberg. 1985. Identification of a cell surface protein complex mediating phorbol ester-induced adhesion (binding) among human mononuclear leukocytes. Scand. J. Immunol. 22:171-176.

16. Keizer, G. D., J. Borst, C. G. Figdor, H. Spits, F. Miedema, C. Terhorst, and J. E. DeVries. 1985. Biochemical and functional characteristics of the human leukocyte membrane antigen family LFA-1, Mol, and p150,95. Eur. J. Immunol. 15:1142-1148.

17. Tedder, T. F., A. W. Boyd, A. S. Freedman, L. M. A. Nadler, and S. F. Schlossman. 1985. The B cell surface molecule B1 is functionally linked with B cell activation and differentiation. J. Immunol. 135:972979.

18. Hunkapillar, M. W., E. Legan, F. Ostrander, and L. R. Hood. 1983. Isolation of microgram quantities of proteins from polyacrylamide gels for amino acid sequence analysis. Methods Enzymol. 91:227-236.

19. Towbin, H., T. Staehelin, and J. Gordon. 1979. Electrophoretic transfer of proteins from polyacrylamide gels to nitrocellulose sheets. Procedure and some applications. Proc. Natl. Acad. Sci. USA. 76:43504354.

20. Laemmli, U. K. 1970. Cleavage of structural proteins during the assembly of the head of bacteriophage T4. Nature (Lond.). 227:680-685.

21. Laskey, R. A., and A. D. Mills. 1975. Quantitative film detection of ${ }^{3} \mathrm{H}$ and ${ }^{14} \mathrm{C}$ in polyacrylamide gels by fluorography. Eur. J. Biochem. $56: 335-341$.

22. Atkinson, J. P., and E. A. Jones. 1984. Biosynthesis of the human $\mathrm{C} 3 \mathrm{~b} / \mathrm{C} 4 \mathrm{~b}$ receptor during differentiation of the HL60 cell line. Identification \& characterization of a precursor molecule. J. Clin. Invest. 74: 1649-1657.

23. Chirgwin, J. M., A. E. Przybyla, R. J. MacDonald, and W. J. 
Rutter. 1979. Isolation of biologically active ribonucleic acid from sources enriched in ribonuclease. Biochemistry. 18:5294-5299.

24. Aviv, H., and P. Leder. 1972. Purification of biologically active globin messenger RNA by chromatography on oligothymidilic acid-cellulose. Proc. Natl. Acad. Sci. USA. 69:1408-1412.

25. Cleveland, D. W., M. A. Lopata, R. J. MacDonald, N. J. Cowan, W. J. Rutter, and M. W. Kirschner. 1980. Number and evolutionary conservation of alpha- and beta-tubulin and cytoplasmic beta- and alphaactin genes using specific cloned cDNA probes. Cell. 20:95-105.

26. Thomas, P. S. 1980. Hybridization of denatured RNA and small DNA fragments transferred to nitrocellulose. Proc. Natl. Acad. Sci. USA. 77:5201-5205.

27. Feinberg, A. P., and B. Vogelstein. 1984. A technique for ra- diolabelling DNA restriction endonuclease fragments to high specific activity. Anal. Biochem. 137:266-267.

28. Dunphy, W. G., E. Fries, L. J. Urbani, and J. E. Rothman. 1981. Early and late functions associated with the Golgi apparatus reside in distinct compartments. Proc. Natl. Acad. Sci. USA. 78:7453-7457.

29. Haguenauer-Tsapis, R., and A. Hinnen. 1984. A deletion that includes the signal-peptidase cleavage site impairs processing, glycosylation and secretion of cell surface yeast acid phosphatase. Mol. Cell Biol. 4:2668-2675.

30. Yamamoto, T., R. W. Bishop, M. S. Brown, J. L. Goldstein, D. W. Russell. 1986. Deletion in cysteine-rich region of LDL receptor impedes transport to cell surface in WHHL rabbit. Science (Wash. DC). 232:1230-1237. 